\title{
DAMPAK EKONOMI AKIBAT KEJAHATAN KORUPSI PASCA REGULASI OTONOMI DAERAH ${ }^{*}$
}

\author{
Nur Rohim ${ }^{1}$ \\ Permalink: https://www.academia.edu/9989964
}

\begin{abstract}
Economic Impact Due to Corruption Crime After the existence of Regulatory Autonomy. Regional autonomy is regarded by the government as an antidote to regional political turmoil. It has been promised as an antidote to the highly centralized political and financial structures that never applied before. However, this expectation even leads to a shift of the corruption that was originally located in the center turning to the area. Therefore, it adversely affects economic improvement and welfare of the area. In example, there is emergence of new modes, either by manipulating the production and illegal cutting of the opinion.
\end{abstract}

Keywords: Economic Impact, Corruptions, Regulatory Autonomy

\begin{abstract}
Abstrak: Dampak Ekonomi Akibat Kejahatan Korupsi Pasca Regulasi Otonomi Daerah. Otonomi daerah dianggap oleh pemerintah sebagai obat penawar gejolak politik daerah. Kebijakan ini dijanjikan sebagai suatu kutub berlawanan terhadap sistem politik dan struktur keuangan terpusat yang pernah diterapkan sebelumnya. Akan tetapi harapan ini malah berujung kepada pergeseran korupsi yang semula berada di pusat beralih ke daerah, sehingga berdampak ekonomi bagi peningkatan kesejahteraan rakyat daerah. Seperti munculnya modus-modus baru, baik dengan memanipulasi pengeluaran daerah maupun memotong secara ilegal pendapat daerah.
\end{abstract}

Kata Kunci: Dampak Ekonomi, Korupsi, Otonomi Daerah

* Diterima tanggal naskah diterima: 02 Maret 2014, direvisi: 25 April 2014, disetujui untuk terbit: 10 Juni 2014.

${ }^{1}$ Fakultas Syariah dan Hukum UIN Jakarta. Alamat: Jl. Ir. Juanda No. 95 Ciputat Jakarta. E-mail: nurroyun@yahoo.com 


\section{Pendahuluan}

Saat Indonesia dilanda ketidakpastian besar dalam bidang ekonomi, politik, ekologi, hukum dan sosial, maka otonomi daerah menjadi salah satu wacana besar yang membayangi masa depan negeri. Ditandai dengan krisis keuangan yang mengawali kejatuhan Suharto yang berlarut-larut, meskipun sudah ada intervensi yang dipimpin oleh IMF, namun perekonomian tetap berjalan seperti semula dan beban hutang nasional Indonesia yang makin besar dimunculkan ke permukaan.

Belum lagi krisis kepercayaan terhadap pemerintah yang dimulai kurang lebih sepuluh bulan sejak berkuasanya pemerintahan Presiden Abdurahman Wahid yang dipilih secara demokratis. Hal itu terlihat dengan adanya wujud pemerintahan yang lemah dan terpecah-pecah dalam upaya reformasi yang tidak merata. Konflik berdarah di Maluku terus berlanjut yang menyebabkan tewasnya ratusan jiwa. Aceh dan Papua semakin keras menuntut kemerdekaannya. Krisis ekologis semakin mendalam karena penebangan legal dan ilegal telah mencabik-cabik wilayah hutan yang luas dan menyebabkan kebakaran hutan terhadap bagian yang tersisa. Kaum miskin di Indonesia -yang dipinggirkan selama tiga dekade kekuasaan Suharto- semakin dimiskinkan oleh kejatuhan ekonomi dan kehancuran sumber daya alam mereka yang semakin dipercepat. Belum lagi tuntutan disintegrasi bangsa dari beberapa daerah, seperti Aceh, Papua, Maluku dan Riau. Oleh karena itulah, tak heran bila akhirnya slogan Otonomi Daerah yang diangkat dan diusung dirasa dapat menjadi alternatif terbaik guna mengatasi krisis yang berkepanjangan tersebut.

Permasalahan yang akan menjadi fokus dalam penulisan ini adalah seberapa jauhkah dampak yang dapat dihasilkan dengan keberadaan otonomi daerah? Apakah otonomi daerah benar-benar mampu menjadi solusi akhir guna mengatasi problematika bangsa? Apakah ada peluang korupsi dari adanya kebijakan otonomi daerah tersebut? Apa solusi yang dapat diberikan?

Dengan adanya kebijakan pemerintah melalui otonomi daerah, maka upaya menciptakan kesejahteraan rakyat yang menyeluruh menjadi slogan utama. Walau pun pada realitanya penyakit budaya warisan bangsa kolonial korupsi- masih mewabah di era otonomi daerah, sehingga cita-cita untuk menciptakan kesejahteraan rakyat menjadi terganggu.

Oleh karena itulah, penulisan karya ilmiah ini dipandang perlu, agar penyakit masyarakat yang masih benjangkit dapat dicarikan solusi dan penanggulangannya, khususnya di daerah-daerah.

\section{Otonomi Daerah di Indonesia}

Otonomi diartikan "pemerintahan sendiri" (Auto $=$ sendiri, nomes= pemerintahan). ${ }^{2}$ Otonomi daerah diadakan bukan hanya untuk menjamin

\footnotetext{
2 Amrah Muslimin, Aspek-Aspek Hukum Otonomi Daerah, (Bandung: Alumni,
} 1982), h. 6. 
efisiensi penyelenggaraan pemerintahan, namun juga merupakan cara untuk memelihara negara kesatuan. ${ }^{3}$

Otonomi daerah merupakan masalah yang cukup rumit mengingat ia bukan semata-mata pengalihan kekuasaan dari Jakarta ke tingkat daerah. Tetapi juga berkaitan dengan masalah perkembangan demokrasi pada tingkat lokal dengan melibatkan perubahan-perubahan besar dalam sendi perekonomian. Selain juga memunculkan persoalan mendasar tentang arah masa depan dan bentuk Indonesia sebagai negara demokratis.

Otonomi daerah dianggap oleh pemerintah sebagai obat penawar gejolak politik. Kebijakan ini dijanjikan sebagai suatu kutub berlawanan terhadap sistem politik dan struktur keuangan terpusat yang digunakan mantan Presiden Suharto sebagai cara mendapatkan keuntungan dari sumber daya alam di Indonesia. Sistem ini juga telah menyingkirkan masyarakat dari mata pencaharian mereka. Tetapi kebijakan ini juga telah ditolak sebagai upaya sinis pemerintah pusat membohongi penduduk untuk percaya bahwa pemerintah pusat bersedia berbagi kekuasaan, sementara dalam kenyataan mereka enggan melakukannya.

Setelah jatuhnya Suharto, pemerintahan transisi Presiden Habibie mengesahkan sebuah undang-undang baru pada tahun 1999. Undang-undang ini memberikan kekuasaan kepada pemerintahan daerah untuk membuat kebijakan dan keuangan sendiri. Terlihat bahwa tindakan ini merupakan reaksi tergesa-gesa terhadap kontrol terpusat yang korup dan represif selama beberapa dekade. Pemerintah nampaknya harus memenuhi tuntutan demokrasi dan reformasi jika mereka ingin menghindari gejolak sosial yang lebih parah yang mencirikan bulan-bulan terakhir kekuasaan Suharto. Tekanan untuk melakukan reformasi politik datang dari wilayah-wilayah yang kaya dengan sumber daya alam. Mereka sangat marah terhadap kekayaan alam mereka dikuras hanya untuk menebalkan dompet kaki tangan Suharto. Namun pada saat yang sama, krisis keuangan Indonesia yang berlarut-larut nampaknya menjadi insentif ekonomis yang kuat untuk melakukan desentralisasi. Hal ini akan meringankan beban biaya birokrasi yang besar, di mana pemerintah pusat merasa berat membayarkannya, hingga akhirnya mengalihkan beban tersebut di pundak pemerintah daerah.

Bulan-bulan setelah kejatuhan Suharto ditandai suatu euforia yang diikuti dengan pertikaian politik dan ketidakpastian. Tuntutan yang semakin kuat untuk merdeka di Aceh dan Papua Barat diikuti pula dengan tuntutan sistem federal dari Riau, Maluku, Sulawesi Utara dan Kalimantan Timur. Namun, daripada membahas masalah federasi ini secara terbuka, pemerintahan Habibie berupaya keras menolak tuntutan itu dan menjanjikan suatu otonomi lokal. Meskipun demikian, apa yang ditawarkan dalam otonomi lokal tidak dibuat dengan jelas: desentralisasi pemerintahan atau pengalihan kekuasaan?

Bersamaan dengan beberapa undang-undang baru yang lainnya, undang-undang tentang otonomi daerah diajukan dalam bulan-bulan terakhir

3 Bagir Manan, Menyongsong Fajar Otonomi Daerah, (Yogyakarta: Pusat Studi Hukum (PSH) Hukum UII, 2001), h. 3. 
sebelum pemilu bulan Juni 1999. Hasilnya adalah undang-undang otonomi daerah yang sangat lemah. Undang-undang itu melebih-lebihkan persoalan penting tentang tingkat pertanggungjawaban kekuasaan daerah dan pusat, khususnya dalam bidang pembuatan kebijakan dan pengelolaan sumber daya alam. Namun yang lebih membingungkan adalah peraturan pelaksana undangundang tersebut.

Berbagai jenis aktor di panggung politik Indonesia mencoba menginterpretasikan penerapan undang-undang nomor 22 dan nomor $25 \mathrm{itu}^{4}$ untuk memenuhi kepentingan mereka. Ringkasnya, ini merupakan suatu gabungan yang amat kompleks dan secara politik mudah meledak.

Bagi Presiden Abdurrahman Wahid, tujuan utama melanjutkan kebijakan otonomi daerah yang diwarisi oleh pemerintahan Habibie adalah untuk mencegah proses disintegrasi di Indonesia. Gus Dur menyalahkan sebagian besar persoalan yang dialami oleh negeri ini terhadap sistem terpusat di masa lalu dan melihat kebutuhan untuk "otonomi penuh" di daerah. ${ }^{5}$

Tetapi, upaya untuk "menyelamatkan" negara kesatuan Indonesia telah ditolak oleh gerakan kemerdekaan di Aceh dan Papua Barat. Pada bulan Juni 2000, para pemimpin Gerakan Aceh Merdeka, GAM, diikuti proklamasi sepihak oleh Republik Maluku Selatan (RMS), mengumumkan akan melakukan kerja sama mereka dalam perjuangan kemerdekaan.

Bagi kebanyakan daerah lainnya, persoalan otonomi daerah memiliki arti yang sangat penting. Desentralisasi pengawasan, jika hal ini bisa terus berjalan dalam pengertian yang nyata, akan memiliki pengaruh mendalam terhadap kehidupan masyarakat adat dan masyarakat desa. Selain itu, ia juga berpengaruh terhadap cara pengolahan sumber daya alam di Indonesia.

Bagi masyarakat lokal, hutan, tanah, air bersih dan sumber daya laut di mana mereka bergantung, otonomi daerah akan berhasil atau gagal tergantung pada apakah ia akan membantu menghentikan gelombang penghancuran yang melanda sebagian besar wilayah Indonesia.

Berbagai organisasi Rakyat Indonesia dan LSM yakin bahwa ujian yang sesungguhnya akan terletak pada kekuatan demokrasi pada tingkat lokal seberapa cepat dan seberapa jauh masyarakat lokal dapat menjamin bahwa mereka dapat mengambil bagian penuh dalam pembuatan keputusan terhadap pengelolaan dan perlindungan sumber daya alam.

Secara ideal, keberhasilan akan memberikan pengawasan demokratis terhadap proses pembentukan kebijakan, penegakan hukum yang efektif, pemerintahan daerah yang bersih dan transparan. Proses ini juga akan memberikan peluang penggunaan sumber daya alam berkelanjutan untuk kepentingan seluruh masyarakat sekarang dan di masa yang akan datang. Di sisi

${ }^{4}$ Yaitu Undang-Undang No. 22 tahun 1999 tentang Pemerintahan Daerah dan Undang-Undang No. 25 tahun 1999 tentang Perimbangan Keuangan antara Pemerintah Pusat dan Daerah.

${ }^{5}$ Dalam suatu pidato yang diucapkannya pada beberapa tahun lalu di depan pertemuan akbar Partai Demokrasi Indonesia Perjuangan "Apapun yang terjadi, negeri ini tidak boleh terpecah belah. Tidak boleh ada wilayah yang memisahkan diri dari Indonesia dan kita akan tetap bersatu." (AFP, 27/Jan/00). 
lain, dari segi yang terburuk, kegagalan akan menyebabkan pengalihan kekuasaan kepada pusat-pusat pemerintahan daerah dengan para pemimpinnya yang bertingkah seperti tiran kecil dan hanya mencontoh ulang praktek-praktek perampokan sumber daya alam pada era Suharto untuk keuntungan pribadi secara maksimal di tingkat daerah. Atau - jika pemerintahan pusat tetap bersikeras untuk mempertahankan kontrol mereka, hasilnya mungkin adalah ketidakadilan sosial yang sama dan pelanggaran lingkungan yang seringkali dikaitkan dengan pemusatan kekuasaan di Jakarta sampai sekarang. Hal ini akan mengakibatkan ledakan gejolak sosial dan ketidakstabilan politik yang lebih besar.

\section{Perkembangan UU Otonomi Daerah}

Meskipun UUD 1945 yang menjadi acuan konstitusi telah menetapkan konsep dasar tentang kebijakan otonomi kepada daerah-daerah, tetapi dalam perkembangan sejarah ide otonomi daerah itu mengalami berbagai perubahan bentuk kebijakan yang disebabkan oleh kuatnya tarik-menarik kalangan elit politik pada masanya. Apabila perkembangan otonomi daerah dianalisis sejak tahun 1945, akan terlihat bahwa perubahan-perubahan konsepsi otonomi banyak ditentukan oleh para elit politik yang berkuasa pada saat itu. Hal itu terlihat jelas dalam aturan-aturan mengenai pemerintahan daerah sebagaimana yang terdapat dalam UU berikut ini :

Pertama; UU No. 1 tahun 1945. Kebijakan Otonomi daerah pada masa ini lebih menitikberatkan pada dekonsentrasi. Kepala daerah hanyalah kepanjangan tangan pemerintahan pusat.

Kedua; UU No. 22 tahun 1948. Mulai tahun 1948, kebijakan otonomi daerah lebih menitikberatkan pada desentralisasi. Walaupun dalam pelaksanaannya masih ada dualisme peran di kepala daerah, di satu sisi berperan besar untuk daerah, di sisi lain menjadi alat pemerintah pusat.

Ketiga; UU No. 1 tahun 1957. Kebijakan otonomi daerah pada masa ini masih bersifat dualisme, di mana kepala daerah bertanggung jawab penuh pada DPRD, tetapi juga masih alat pemerintah pusat.

Keempat; Penetapan Presiden No.6 tahun 1959. Pada masa ini kebijakan otonomi daerah lebih menekankan dekonsentrasi. Melalui penpres ini kepala daerah diangkat oleh pemerintah pusat terutama dari kalangan pamong praja.

Kelima; UU No. 18 tahun 1965. Pada masa ini kebijakan otonomi daerah menitikberatkan pada desentralisasi dengan memberikan otonomi yang seluas-luasnya bagi daerah, sedangkan dekonsentrasi diterapkan hanya sebagai pelengkap saja.

Keenam; UU No. 5 tahun 1974. Setelah terjadinya G.30.S PKI pada dasarnya telah terjadi kevakuman dalam pengaturan penyelenggaraan pemerintahan di daerah sampai dengan dikeluarkanya UU NO. 5 tahun 1974 yaitu desentralisasi, dekonsentrasi dan tugas perbantuan. Sejalan dengan kebijakan ekonomi pada awal Ode Baru, maka pada masa berlakunya UU No. 5 tahun 1974 pembangunan menjadi isu sentral dibanding dengan politik. Pada penerapannya, terasa seolah-olah telah terjadi proses depolitisasi peran 
pemerintah daerah dan menggantikannya dengan peran pembangunan yang menjadi isu nasional.

Ketujuh; UU No. 22 tahun 1999 tentang Pemerintahan Daerah. Pada masa ini terjadi lagi perubahan yang menjadikan pemerintah daerah sebagai titik sentral dalam penyelenggaraan pemerintahan dan pembangunan dengan mengedapankan otonomi luas, nyata dan bertanggung jawab. ${ }^{6}$

Kedelapan; Undang-Undang Republik Indonesia Nomor 25 tahun 1999 tentang perimbangan keuangan antara pemerintah pusat dan daerah.

Kesembilan; Peraturan Pemerintah Republik Indonesia Nomor 25 tahun 2000 tentang kewenangan pemerintah dan kewenangan propinsi sebagai daerah otonom.

Kesepuluh; Peraturan Pemerintah Republik Indonesia Nomor 104 tahun 2000 tentang Dana Perimbangan.

Kesebelas; Keputusan Presiden Republik Indonesia Nomor 49 tahun 2000 tentang Dewan Pertimbangan Otonomi Daerah Presiden Republik Indonesia.

Keduabelas; Keputusan Presiden Republik Indonesia Nomor 84 tahun 2000 tentang perubahan atas Keputusan Presiden Nomor 49 tahun 2000 tentang Dewan Pertimbangan Otonomi Daerah.

Ketigabelas; Keputusan Presiden Republik Indonesia Nomor 52 tahun 2000 tentang pembentukan tim koordinasi tindak lanjut pelaksanaan undangundang nomor 22 tahun 1999 tentang pemerintahan daerah dan undangundang nomor 25 tahun 1999 tentang perimbangan keuangan antara pemerintah pusat dan daerah.

\section{Modus Korupsi ${ }^{7}$ Di Daerah Pasca Otonomi Daerah}

Setelah Gubernur Nanggroe Aceh Darussalam resmi menjadi tersangka korupsi pembelian genset senilai Rp 30 miliar, lalu giliran Gubernur Sumatera Barat Zainal Bakar resmi sebagai tersangka kasus korupsi anggaran dewan dalam APBD 2002 sebesar Rp 6,4 miliar. Dua kasus korupsi menyangkut gubernur ini, masih ditambah hujan kasus korupsi yang menyangkut puluhan anggota Dewan Perwakilan Rakyat Daerah di berbagai wilayah di Indonesia, dengan modus mirip berupa penyelewengan dana APBD. ${ }^{8}$

Kasus-kasus tersebut dinilai peneliti The Habibie Center, Andrinof A.Chaniago merupakan salah satu akibat meningkatnya kekuasaan legislatif maupun eksekutif di daerah. Hal itu dimungkinkan karena dalam UU No. 22 tahun 1999 tentang pemerintah daerah, anggaran dewan memiliki hak besar

6 - Lihat: Perkembangan Otonomi Daerah di Indonesia, www.infogeocities.com.

7. Korupsi ialah menyalahgunakan atau menggelapkan uang/harta kekayaan umum (negara, rakyat atau orang banyak) untuk kepentingan pribadi. Praktik korupsi biasanya dilakukan oleh pejabat yang memegang suatu jabatan pemerintah. Dalam istilah politik bahasa Arab, korupsi sering disebut 'al-fasad' atau 'risywah'. Tetapi yang lebih spesifik ialah 'ikhtilas' atau 'nahb al-amwal al-ammah". (Lihat: Daud Rasyid, Islam dan Reformasi, (Jakarta: Usama Press, 2001, h. 65.

${ }^{8}$-Fitri Oktarini, Tempo, http://www.tempointeraktif.com/hg/narasi/2004/11/04/nrs, $\underline{\text { 20041104-01,id.html }}$ 
untuk mengatur anggaran. Tapi, undang-undang tersebut tidak mengatur mekanisme pertanggungjawaban yang transparan kepada publik. Tidak heran jika wewenang yang besar itu justru melahirkan penyimpangan, yaitu mengalirkan dana negara ke kantong pribadi. Lebih parahnya, upaya memperkaya diri itu dilakukan secara massal, sehingga berat di hak, lemah di kewajiban.

Dampaknya timbul ketidakjelasan akuntabilitas kepala daerah terhadap masyarakat setempat, yang membuat bentuk-bentuk tanggungjawab kepala daerah ke publik pun menjadi belum jelas. Karena posisi masyarakat dalam proses penegakan prinsip akuntabilitas dan transparansi pemerintah daerah belum jelas, sehingga publik tidak pernah tahu bagaimana kinerja birokrasi di daerah.

Pada dasarnya korupsi di tingkat daerah merupakan bentuk kerjasama yang manis antara kekuasaan politik di daerah, dengan kelompok kepentingan tertentu, sehingga menghasilkan koruptor-koruptor daerah yang diktaktor. Ini merupakan corruption by design, karena 75 persen Perda yang lahir untuk meningkatkan pendapatan asli daerah yang malah sarat korupsi.

Untuk itu selain dicantumkan prosedur administrasi dalam pertanggungjawaban anggota Dewan, juga perlu ada prosedur politik yang melibatkan masyarakat dalam mengawasi pelaksanaan APBD. Misalnya, dengan adanya rapat terbuka atau laporan rutin ke masyarakat melalui media massa.

Menurut Data yang bersumber dari The Habibie Center ada beberapa modus korupsi di daerah. Sebagaimana berikut:

\begin{tabular}{|c|l|l|}
\hline No & \multicolumn{1}{|c|}{ Kasus } & \multicolumn{1}{c|}{ Modusnya } \\
\hline 1 & Korupsi Pengadaan Barang & $\begin{array}{l}\text { a. Penggelembungan (mark up) nilai barang dan } \\
\text { jasa dari harga pasar. } \\
\text { b. Kolusi dengan kontraktor dalam proses tender. }\end{array}$ \\
\hline 2 & $\begin{array}{l}\text { Penghapusan barang inventaris dan } \\
\text { aset negara (tanah) }\end{array}$ & $\begin{array}{l}\text { a. Memboyong inventaris kantor untuk } \\
\text { kepentingan pribadi. } \\
\text { b. Menjual inventaris kantor untuk kepentingan } \\
\text { pribadi. }\end{array}$ \\
\hline 3 & $\begin{array}{l}\text { Pungli penerimaan pegawai, } \\
\text { pembayaran gaji, kenaikan pangkat, } \\
\text { pengurusan pensiun dan sebagainya. }\end{array}$ & $\begin{array}{l}\text { Memungut biaya tambahan di luar ketentuan } \\
\text { resmi. }\end{array}$ \\
\hline 4 & $\begin{array}{l}\text { Pemotongan uang bantuan sosial dan } \\
\text { subsidi (sekolah, rumah ibadah, panti } \\
\text { asuhan dan jompo) }\end{array}$ & $\begin{array}{l}\text { a. Pemotongan dana bantuan sosial. } \\
\text { b. Biasanya dilakukan secara bertingkat (setiap } \\
\text { meja). }\end{array}$ \\
\hline 5 & Bantuan fiktif & $\begin{array}{l}\text { Membuat surat permohonan fiktif seolah-olah ada } \\
\text { bantuan dari pemerintah ke pihak luar. }\end{array}$ \\
\hline 6 & $\begin{array}{l}\text { Penyelewengan dana proyek } \\
\text { a. Mengambil dana proyek pemerintah di luar } \\
\text { ketentuan resmi. } \\
\text { b. Memotong dana proyek tanpa sepengetahuan } \\
\text { orang lain. }\end{array}$ \\
\hline
\end{tabular}

9 - The Habibie Center, http://www.tempointeraktif.com/hg/narasi/2004/11/04/nrs, $\underline{\text { 20041104-01,id.html }}$ 


\begin{tabular}{|c|c|c|}
\hline 7 & Proyek fiktif fisik & $\begin{array}{l}\text { Dana dialokasikan dalam laporan resmi, tetapi } \\
\text { secara fisik proyek itu nihil. }\end{array}$ \\
\hline 8 & $\begin{array}{l}\text { Manipulasi hasil penerimaan } \\
\text { penjualan, penerimaan pajak, retribusi } \\
\text { dan iuran. }\end{array}$ & $\begin{array}{l}\text { a. Jumlah riil penerimaan penjualan, pajak tidak } \\
\text { dilaporkan. } \\
\text { b. Penetapan target penerimaan pajak lebih } \\
\text { rendah dari penerimaan riil. }\end{array}$ \\
\hline 9 & $\begin{array}{l}\text { Manipulasi proyek-proyek fisik (jalan, } \\
\text { jembatan, bangunan, kantor, sekolah, } \\
\text { asrama) }\end{array}$ & $\begin{array}{l}\text { a. Mark up nilai proyek. } \\
\text { b. Pungutan komisi tidak resmi terhadap } \\
\text { kontraktor. }\end{array}$ \\
\hline 10 & Daftar Gaji atau honor fiktif & Pembuatan pekerjaan fiktif. \\
\hline 11 & $\begin{array}{l}\text { Manipulasi dana pemeliharaan dan } \\
\text { renovasi fisik. }\end{array}$ & $\begin{array}{l}\text { a. Pemotongan dana pemeliharaan. } \\
\text { b. Mark up dana pemeliharaan dan renovasi fisik. }\end{array}$ \\
\hline 12 & $\begin{array}{l}\text { Pemotongan dana bantuan (inpres, } \\
\text { banpres) }\end{array}$ & $\begin{array}{l}\text { Pemotongan langsung atau tidak langsung oleh } \\
\text { pegawai atau pejabat berwenang. }\end{array}$ \\
\hline 13 & $\begin{array}{l}\text { Proyek pengembangan Sumber Daya } \\
\text { Manusia (SDM) secara fiktif (tidak ada } \\
\text { proyek atau intensitas) }\end{array}$ & $\begin{array}{l}\text { Tidak ada proyek atau intensitas yang tidak } \\
\text { sesuai laporan. Misalnya kegiatan dua hari } \\
\text { dilaporkan empat hari. }\end{array}$ \\
\hline 14 & $\begin{array}{l}\text { Manipulasi ganti rugi tanah dan } \\
\text { bangunan }\end{array}$ & $\begin{array}{l}\text { Pegawai atau pejabat pemerintah yang } \\
\text { berwenang tidak memberikan harga ganti rugi } \\
\text { secara wajar atau yang disediakan. }\end{array}$ \\
\hline 15 & $\begin{array}{l}\text { Manipulasi biaya sewa fasilitas dan } \\
\text { transportasi }\end{array}$ & $\begin{array}{l}\text { Manipulasi biaya penyewaan fasilitas pemerintah } \\
\text { kepada pihak luar. }\end{array}$ \\
\hline 16 & $\begin{array}{l}\text { Pembayaran fiktif uang lauk pauk } \\
\text { Pegawai Negeri sipil, prajurit, tahanan } \\
\text { dan lain-lain }\end{array}$ & $\begin{array}{l}\text { a. Alokasi fiktif uang lauk pauk Pegawai Negeri } \\
\text { Sipil, prajurit tahanan dalam catatan resmi seperti } \\
\text { APBD. } \\
\text { b. Menggunakan kuitansi fiktif. }\end{array}$ \\
\hline 17 & $\begin{array}{l}\text { Pungli Perizinan; IMB, sertifikat } \\
\text { SIUPP, besuk tahanan, ijin tinggal, ijin } \\
\text { TKI, ijin frekuensi, impor ekspor, } \\
\text { pendirian apotik, RS, klinik, Delivery } \\
\text { Order pembelian sembilan bahan } \\
\text { pokok agen dan distributor. }\end{array}$ & $\begin{array}{l}\text { a. Memungut biaya tak resmi kepada anggota } \\
\text { masyarakat yang mengurus perijinan. } \\
\text { b. mark up biaya pengurusan ijin. } \\
\text { c. Kolusi dengan pengusaha yang mengurus ijin. }\end{array}$ \\
\hline 18 & Pungli kependudukan dan Imigrasi & $\begin{array}{l}\text { a. Memungut biaya tidak resmi kepada anggota } \\
\text { masyarakat yang mengurus perijinan. } \\
\text { b. mark up biaya pengurusan ijin. } \\
\text { c. Kolusi dengan pengusaha yang mengurus ijin. }\end{array}$ \\
\hline 19 & $\begin{array}{l}\text { Manipulasi Proyek Pengembangan } \\
\text { Ekonomi Rakyat. }\end{array}$ & Penyerahan dalam bentuk uang. \\
\hline 20 & Korupsi waktu kerja & $\begin{array}{l}\text { a. Meninggalkan pekerjaan } \\
\text { b. Melayani calo yang memberi uang tambahan } \\
\text { c. Menunda pelayanan umum }{ }^{10}\end{array}$ \\
\hline
\end{tabular}

\section{Gejala Penyebab Korupsi}

Merujuk pada pemberlakuan UU No. 22 tahun 1999 dan UU No. 25 tahun 1999 kondisi empirik keuangan daerah memang menunjukkan gejalagejala yang memungkinkan untuk melakukan korupsi di daerah. Seorang Direktur Fasilitasi Kebijakan dan Pelaporan Otda sekaligus Direktur Jenderal

${ }^{10}$ - The Habibie Center, http://www.tempointeraktif.com/hg/narasi/2004/11/04/nrs, 20041104-01,id.html 
Otonomi Daerah Departemen Dalam Negri ${ }^{11}$, Made Suwandi menyatakan bahwa gejala-gejala tersebut antara lain: ${ }^{12}$

Pertama; Konflik penguasaan kewenangan yang menghasilkan penerimaan. Permasalahan aktual yang dihadapi dalam aspek keuangan dalam masa transisi adalah timbulnya kecenderungan rebutan kewenangan antar tingkatan pemerintahan untuk memperoleh sumber-sumber keuangan yang berasal dari wewenang tersebut. Kewenangan-kewenangan yang menghasilkan sumber penerimaan cenderung bermasalah, sedangkan kewenangan yang kurang menghasilkan penerimaan cenderung untuk dihindari. Sebagai contoh, pelayanan rumah sakit jiwa cenderung untuk saling lempar tanggungjawab dalam penanganannya. ${ }^{13}$

Menurut penulis hal tersebut menjadi batu loncatan bagi pihak yang berwenang untuk bertindak sewenang-wenang menentukan hal apa yang memungkinkan Pemerintah Daerah untuk menghasilkan keuangan. Sehingga dengan peluang tersebut, setiap aparat akan bertindak seenaknya dengan mengatasnamakan Pemda setempat. Hal ini tidak menutup kemungkinan adanya peluang korupsi, karena tidak adanya pengawasan secara formal dari instansi setempat.

Kedua; Keuangan daerah yang kurang mencukupi (Financial Insufficiency). Luasnya kewenangan otonomi daerah dijadikan alasan utama untuk meningkatkan sumber-sumber penerimaan daerah. Akibatnya muncul berbagai pungutan daerah yang tidak jelas hubungan dengan pelayanan yang diberikan daerah. Pungutan tersebut menyebabkan economic in-effeciency yang dibebankan ke konsumen ataupun menyebabkan kurang kompetitifnya ekonomi daerah dan nasional.

Tidak adanya Standar Pelayanan Minimum (SPM) juga menjadi pemicu ketidakmampuan daerah untuk menghitung kebutuhan fiscal daerah dan ketidakmampuan menghitung agregat biaya yang dibutuhkan daerah. Akibatnya daerah selalu merasa kekurangan dana dan memicu kecenderungan untuk mencari sumber-sumber kewenangan baru yang dapat menghasilkan penerimaan daerah. ${ }^{14}$

Hal inipun menurut penulis, bila tidak dicermati secara khusus malah menambah kesan yang buruk akan adanya otonomi daerah. Ditambah tidak adanya standar Pelayanan Minimum yang ditentukan, sehingga setiap aparat Pemda dapat melakukan tindakan seenaknya dengan dalih sesuai presedur yang ada. Contoh yang kongkrit adalah, memungut biaya tidak resmi kepada anggota masyarakat yang mengurus perijinan, kolusi dalam penerimaan pegawai baru dan lain sebagainya.

Ketiga; Kurangnya kepatuhan pada peraturan dan lemahnya penegakan hukum. Walaupun PP No 109 tahun 2000 dan PP No 110 tahun 2000

\footnotetext{
${ }^{11}$ - Menjabat pada masa pemerintahan KH. Abdurrahman Wahid, tahun 2002.

${ }^{12}$ - Lihat: Made Suwandi, Konsepsi Dasar Otonomi Daerah Indonesia, Jakarta, 2002, h. 19-21.

13 - Made Suwandi, Konsepsi Dasar Otonomi Daerah Indonesia, h. 19-21.

14. Made Suwandi, Konsepsi Dasar Otonomi Daerah Indonesia, h. 19-21
} 
mengatur kedudukan keuangan dari kepada daerah dan DPRD. Sebagian besar dari mereka tidak mengikuti pembiayaan yang ditetapkan oleh PP tersebut karena menganggap bahwa otonomi berarti daerah dapat melakukan apa saja yang sesuai dengan keinginan mereka. Beberapa daerah bahkan menolak kehadiran aparat pengawasan pusat dengan alasan otonomi daerah memberi kewenangan sepenuhnya pada daerah dalam memanfaatan keuangan daerah. Kurangnya kontrol dan supervisi adalah sebagai penyebab lemahnya penegakan peraturan. ${ }^{15}$

Kurangnya kepatuhan pada peraturan yang berlaku dengan dalih otonomi daerah juga dapat berdampak adanya ketidakjelasan pemerintah daerah dalam melakukan pengeluaran keuangan. Ada hal-hal yang tidak diperlukan daerah karena ambisi untuk melakukan sirkulasi keuangan dipaksakan untuk dibeli. Sehingga dengan alasan pembelanjaan tersebut, aparat yang bersangkutan dapat mengajukan anggaran keuangan dan memberi laporan yang fiktif-tidak sesuai dengan pengeluaran yang ada.

Keempat; Kurangnya transparansi dan akuntabilitas dalam penyusunan APBD. Rencana-rencana alokasi dana dalam APBD yang mencerminkan kebijakan daerah sering disusun secara kurang transparan dan kurang melibatkan partisipasi masyarakat, sehingga sering menimbulkan protes masyarakat. Hal ini disebabkan belum adanya sistem akuntasi daerah dan belum disusunnya APBD berdasarkan anggaran kinerja sebagaimana diatur dalam PP No 105 tahun 2000. Bila hal ini terus berlanjut, maka kemungkinan adanya peluang untuk melakukan korupsi di setiap lini keuangan menjadi lebih besar. Hal ini -menurut penulis- dapat menjadi pemicu utama perilaku korupsi, karena dengan adanya capability melakukan sistem akuntasi daerah yang baik akan berakibat kerancuan dalam sistem pembukuan daerah.

Kelima; Kurangnya manajemen Aset. Manajemen dan pemanfaatan aset daerah masih sangat rendah. Sangat diperlukan adanya peningkatan kapasitas daerah dan pengaturan mengenai pengelolaan aset daerah. Bila aset daerah kurang termanajemen dengan baik, akan cenderung terjadi prilaku penyalahgunaan aset daerah oleh oknum-oknum yang tidak bertanggungjawab.

Keenam; kebijakan investasi di daerah. Belum ada kejelasan mengenai pengaturan mekanisme investasi di daerah, selain hubungan antara peran pusat dan daerah dalam hal pengelolaan investasi di daerah. Menurut penulis, walau setiap daerah mendapat kebebasan dalam menentukan nasib daerahnya setidaknya harus jelas adanya pengaturan mekanisme investasi, sehingga tidak memberi peluang bagi pihak yang tidak bertanggungjawab untuk ikut mengatur investasi tersebut. Selain itu, harus ada kejelasan peran antara pusat dan daerah dalam pengelolaannya, sehingga tidak ada pihak yang merasa dirugikan, dan pendapatan dan pemasukan yang dihasilkan dapat terdata dengan jelas.

Ketujuh; Pemisahan keuangan eksekutif dengan legislatif. Adanya ketentuan dalam UU No 22 tahun 1999 yang memisahkan anggaran eksekutif dengan legislatif telah menimbulkan penafsiran bahwa masing-masing berhak

\footnotetext{
${ }^{15}$ Made Suwandi, Konsepsi Dasar Otonomi Daerah Indonesia, h. 19-21.
} 
untuk mendapatkan alokasi anggaran. Sering muncul tuntutan persamaan jumlah alokasi anggaran. Akibatnya dana daerah banyak habis untuk overhead cost birokrasi baik politik maupun karir yang ada di lingkungan Pemda. ${ }^{16}$

\section{Dampak Ekonomi Tersebarnya Korupsi Di Daerah} daerah:

Menurut penulis ada beberapa dampak yang disebabkan korupsi di

Pertama; Kemiskinan Penduduk yang statis. Kemiskinan terus menjadi masalah fenomenal sepanjang sejarah Indonesia sebagai nation state, sejarah sebuah negara yang salah memandang dan mengurus kemiskinan. Dalam negara yang salah urus, tidak ada persoalan yang lebih besar, selain persoalan kemiskinan. Kemiskinan telah membuat jutaan anak-anak tidak bisa mengenyam pendidikan yang berkualitas, kesulitan membiayai kesehatan, kurangnya tabungan dan tidak adanya investasi, kurangnya akses ke pelayanan publik, kurangnya lapangan pekerjaan, kurangnya jaminan sosial dan perlindungan terhadap keluarga, menguatnya arus urbanisasi ke kota, dan yang lebih parah, kemiskinan menyebabkan jutaan rakyat memenuhi kebutuhan pangan, sandang dan papan secara terbatas. Kemiskinan, menyebabkan masyarakat desa rela mengorbankan apa saja demi keselamatan hidup, mempertaruhkan tenaga fisik untuk memproduksi keuntungan bagi tengkulak lokal dan menerima upah yang tidak sepadan dengan biaya tenaga yang dikeluarkan. Para buruh tani desa bekerja sepanjang hari, tetapi mereka menerima upah yang sangat sedikit.

Menurut Gregorius Sahdan ${ }^{17}$ dalam artikel Jurnal Ekonomi dan kemiskinan mengatakan, bahwa kemiskinan telah membatasi hak rakyat untuk 1). memperoleh pekerjaan yang layak bagi kemanusiaan; 2). Hak rakyat untuk memperoleh perlindungan hukum; 3). Hak rakyat untuk memperoleh rasa aman; 4). Hak rakyat untuk memperoleh akses atas kebutuhan hidup (sandang, pangan, dan papan) yang terjangkau; 5). Hak rakyat untuk memperoleh akses atas kebutuhan pendidikan; 6). Hak rakyat untuk memperoleh akses atas kebutuhan kesehatan; 7). Hak rakyat untuk memperoleh keadilan; 8). Hak rakyat untuk berpartisipasi dalam pengambilan keputusan publik dan pemerintahan; 9). Hak rakyat untuk berinovasi; 10). Hak rakyat menjalankan hubungan spiritualnya dengan Tuhan; dan 11). Hak rakyat untuk berpartisipasi dalam menata dan mengelola pemerintahan dengan baik. Jadi dengan adanya korupsi yang merajalela di Daerah, maka rakyat yang sudah mengalami kemiskinan tidak akan merasakan perubahan sama sekali, bahkan cenderung lebih miskin. Sebab, Sumber Daya Alam yang semula diniatkan untuk

\footnotetext{
16. Made Suwandi, Konsepsi Dasar Otonomi Daerah Indonesia, (Jakarta, 2002, Hal: 19-21

17- Gregorius Sahdan -- Dosen Jurusan Ilmu Pemerintahan STPMD "APMD” Yogyakarta, Direktur Kajian Politik dan Pembangunan Kawasan Center for Humanity and Civilization Studies (CHOICES), Asisten Ketua STPMD “APMD” Yogyakarta. Lihat: Jurnal Ekonomi Rakyat dan kemiskinan, Maret 2005,
} 
kepentingan Daerah malah disalahgunakan oleh aparat Pemda untuk kepentingan pribadi mereka sendiri.

Kedua; Pendidikan masyarakat yang terbelengkalai. Kemajuan suatu daerah lebih ditopang dari faktor pendidikan masyarakatnya. Bila tingkat pendidikan masyarakat jauh dari standar pengetahuan, tidak menutup kemungkinan suatu daerah akan tetap mundur atau statis dalam kebodohan. Anggaran daerah yang seharusnya dapat dimanfaatkan untuk kepentingan daerah dapat berakibat fatal bagi keberlangsungan kemajuan suatu daerah, apabila lebih diprioritaskan kepada hal-hal yang tidak signifikan.

Bila APBD terbebas dari campurtangan pelaku korupsi, maka hal penting seperti peningkatan tarap pendidikan masyarakat dapat lebih diperhatikan. Seperti pembangunan sarana pendidikan, baik SD, SMP dan SMA di daerah pedesaan.

Ketiga; Rendahnya APBD daerah. APBD dapat menjadi nominal yang rendah dan tidak sesuai dengan keinginan yang telah direncanakan. Besarnya korupsi yang dilakukan Pemda berakibat anggaran yang direncanakan menjadi lebih rendah. Pemda hanya mementingkan besarnya gaji pegawai daerah. Sedang pendapatan daerah yang rendah tidak dapat dikembangkan untuk modal usaha pendapat daerah lainnya. Akibatnya segala sektor kehidupan rakyat menjadi terganggu.

Keempat, Tingginya Pajak untuk meningkatkan Pendapatan Daerah. Kebijakan yang muncul untuk menambah pendapatan daerah setempat yaitu dengan meningkatkan pajak kepada masyarakat. Akibatnya, rakyat bukan bertambah sejahtera tetapi tambah sengsara.

\section{Solusi Penanggulangan}

Untuk mengatasi korupsi yang terjadi di daerah, ada beberapa solusi yang diajukan, diantaranya adalah:

Pertama; Perlunya Pembinaan akhlaqul karimah bagi aparat pemerintahan. Untuk menghindari penyakit korupsi, maka pemda setempat perlu mengadakan kegiatan rutin berupa siraman rohani selama beberapa menit setiap hari, khusus kalangan pegawai Pemerintahan Daerah. Sehingga dengan hal tersebut dapat menghindari berkembangnya penyakit hati $\left(\right.$ wahn $\left.{ }^{18}\right)$ dalam jiwa-jiwa para staf daerah setempat. ${ }^{19}$

Kedua; Perlunya membentuk Badan Pemeriksa Keuangan Daerah yang lebih intensif. Dengan adanya badan pemeriksa keuangan daerah, maka keuangan yang dikeluarkan oleh daerah dapat terpantau dengan baik. Tetapi hendaknya badan ini tidak dibawah koordinasi pemerintah daerah setempat, tetapi berada dibawah langsung pemerintahan diatasnya. Misalnya, Badan Pemeriksa Keuangan Daerah Kabupaten berada secara struktural dibawah Gubernur. Dan Badan pemeriksa keuangan daerah Propinsi berada dibawah menteri dalam negri.

\footnotetext{
${ }^{18}$ - Hubbud Dun-ya (Mencintai dunia dan membenci kematian)

${ }^{19}$ Lihat: Daud Rasyid, Islam dan Reformasi, h. 156.
} 
Ketiga; Penegakan hukuman tambahan terhadap pejabat Pemda yang koruptif. Saat ini Indonesia mengalami krisis ketidakpercayaan terhadap hukum yang berlaku, sehingga terlihat pelaku korupsi selalu dapat berkelit dari jeratan hukuman. Selama ada uang dan aparat peradilan negeri dapat disuap, maka pelaku dapat lepas bebas. Akibatnya, kejahatan korupsi semakin merajalela. Karenanya perlu ada hukuman tambahan bagi penjabat pemda yang melakukan perbuatan korupsi, seperti pemecatan secara tidak terhormat, larangan tinggal di daerah tempat perbuatan dilakukan.

Keempat; Adanya intervensi Pemerintah Pusat dalam bentuk Koreksi dan Revisi UU yang ada. Dalam rangka menjamin terlaksananya undangundang tentang Pemerintahan Daerah, maka hendaklah undang-undang tersebut diposisikan sebagai penjuru bagi segala peraturan perundang-undangan yang berkaitan dengan penyelenggaraan pemerintahan di daerah. Untuk itu, pemerintah pusat perlu mengambil langkah-langkah, seperti melakukan koreksi dan revisi terhadap semua peraturan perundang-undangan yang substansinya tidak sesuai dengan undang-undang tentang pemerintahan daerah dan semangat demokratisasi. Pemerintah pusat juga harus melengkapi semua peraturan pelaksanaan yang diperlukan bagi implementasi kebijakan otonomi daerah.

Kelima; membentuk Peraturan Pemerintah tentang Dekonsentrasi Kewenangan Pusat di daerah. Sebagai konsekuensi dari fungsi pemerintah provinsi sebagai wakil pemerintah pusat di daerah, maka perlu segera diterbitkan PP tentang dekonsentrasi kewenangan pusat kepada provinsi yang dirinci secara jelas dan spesifik, seraya mengoptimalkan fungsi provinsi sebagai koordinator dan pengawas penyelenggaraan pemerintahan daerah di wilayahnya.

Intinya, otonomi daerah yang merupakan bagian dari kebijakan pemerintah pusat untuk mensejahterakan rakyat dalam koridor pengaturan rumah tangga sendiri harus tetap berlandaskan pada pemberdayaan bagi sumber daya manusia di daerah, mengurangi ketergantungan terhadap pemerintah pusat, mandiri dalam pengurusan "rumah dan isi rumah" nya, otonomi tidak hanya memindahkan praktek KKN dari pusat ke daerah, tetapi akan menciptakan sentral-sentral kekuasaan kecil di tiap-tiap daerah, otonomi dapat meredam keinginan beberapa daerah untuk memisahkan diri dari Negara Kesatuan RI.

\section{Penutup}

Berdasarkan uraian yang telah dikemukakan sebelumnya, dapat disimpulkan hal-hal sebagai berikut: a). Otonomi daerah merupakan solusi terciptanya kesejahteraan rakyat yang menyeluruh, dengan terus memantau perkembangan yang terjadi disetiap daerah. b). Penanggulangan korupsi harus tetap menjadi acuan utama di daerah-daerah, sehingga kesejahteraan rakyat yang dicita-citakan benar-benar dapat terwujud.

Ada beberapa saran yang perlu menjadi perhatian yaitu: a). Diperlukan adanya kajian yang lebih intensif dan mendalam, sehingga kebijakan pemerintah yang ditelurkan melalui otonomi daerah dapat berjalan sesuai 
dengan cita-cita awal. b). Diperlukan upaya penyadaran kalangan birokrasi di pemerintah daerah akan adanya dampak negatif dari perilaku kejahatan korupsi terhadap kesejahteraan rakyat. c). Diperlukan wawasan kebangsaan yang menyeluruh, sehingga upaya disintergasi bangsa dapat dihindarkan semaksimal mungkin.

\section{Pustaka Acuan}

Jurnal Ekonomi Rakyat dan kemiskinan, Maret 2005.

Manan, Bagir, Menyongsong Fajar Otonomi Daerah, Yogyakarta: Pusat Studi Hukum (PSH) Hukum UII, 2001.

Muslimin, Amrah, Aspek-Aspek Hukum Otonomi Daerah, Bandung: Alumni, 1982.

Perkembangan Otonomi Daerah di Indonesia, www.infogeocities.com.

Rasyid, Daud, Islam dan Reformasi, Jakarta: Usama Press, 2001.

Suwandi, Made, Konsepsi Dasar Otonomi Daerah Indonesia, Jakarta, 2002.

Fitri Oktarini, Tempo, http://www.tempointeraktif.com/hg/narasi/2004/11/04/nrs,2004110401,id.html

The Habibie Center, http://www.tempointeraktif.com/hg/narasi/2004/11/04/nrs,20041104$\underline{01, \text { id.html }}$ 